I Federal University of Rio Grande do Sul (UFRGS), Porto Alegre, RS, Brazil

emerson.giumbelli@yahoo.com.br

Emerson Giumbelli

\title{
WHEN RELIGION IS CULTURE: OBSERVATIONS ABOUT STATE POLICIES AIMED AT AFRO-BRAZILIAN RELIGIONS AND OTHER AFRO-HERITAGE'
}

\author{
Minha fé minha cultura/Minha fé é meu jogo de cintura \\ (My faith my culture/My faith lets me be flexible) \\ (O Rappa, "Cristo e Oxalá," album Lado B Lado A)
}

In anthropology, culture is a central category. The idea that "everyone - people and groups - has culture" is part of the first lessons on the topic. In social life, however, culture is attributed to collectives and practices in a different way. This text aims to discuss how the concept of Afro-Brazilian religions is established as culture. Although in Brazil it is possible to make this association when considering Catholicism, and even though rarely put into practice when for evangelicals, this connection is an integral part of social views regarding Afro-Brazilian religions. A key field for showing this idea is cultural policies, but the concept that connects religion and culture can be found in other spheres, like the one related to demands for religious freedom. Defining religion as Afro-Brazilian culture makes way for situations that combine religious agents and practices of another nature. I begin this discussion with a description of these situations.

On July 5, 2014, the third annual Ceremonial Cleansing of the Valongo Wharf was held. Wearing party clothes, flowers in hand, perfumed water, and dancing to the sound of musical instruments (atabaques, drums, and agogôs (bells)), mães de santo (priestesses), representatives of candomblé, representatives from various sectors of the so-called black movement in Rio de Janeiro performed the ritual of symbolic cleansing of this place (Carneiro \& Pinheiro, 2015: 392).

Valongo Wharf, located in the center of Brazil's former capital, was one of the main landing points for enslaved Africans in the Americas between the eighteenth and nineteenth centuries. The public works that since 20 I aimed 
at "upgrading" the area related to the city's port neighborhood led to the discovery of the ruins of the old wharf, which had been covered with earth in the nineteenth century. The excavations were incorporated into the "upgrading" project and relied on the work of archaeologists and leaders of the black movement. This endowed the place with the values that were included in the request that demanded it be made into a "world heritage" site by UNESCO.

The meanings and agents involved in cleansing Valongo Wharf call our attention to processes that challenge the status achieved by Afro-Brazilian religions, which is a topic of this text. Carneiro \& Pinheiro (20I5) observe that three mães de santo were in charge of the 2014 event and led most of the activities. Besides black leaders, the event also featured food stands with "baianas de acarajé" (women in traditional Bahian dress who sell acarajé on the street) ${ }^{2}$, and crafts with various "African" items. At the end of the event, several filhos de santo (initiated members) made a circle, then sang another song, and the ceremony concluded with the presentation by a samba school chosen for being "the one that has developed the most plots on the topic of African religion" (Carneiro \& Pinheiro, 20I5: 394). The same authors add: "Today, besides the Valongo Wharf Cleansing Ceremony, many other social events have taken place here, such as, for example, capoeira circles, ${ }^{3}$ exhibitions, celebrations, and several of these show that this space has been a place for meetings, sociability, and the celebration of segments of the Black Movement".

It is noted, therefore, how mães de santo and filhos de santo, with their dress and sounds appear prominently as religious elements at events and speeches that also bring together other agents and meanings. A category that makes it possible to group them all together is "Afro-heritage," a term put forth by the dossier published in France that compiles articles on "Afro-Brazilian culture and dynamics of heritage" (Capone \& Morais, 20I5a). The dossier includes a list of records of "intangible heritage" recognized by the Instituto do Patrimônio Histórico e Artístico Nacional (National Historic and Artistic Heritage Institute, or IPHAN), the federal agency that oversees several cultural policies, including those which act upon events, practices, or knowledge in some way related to this "Afro-Brazilian Culture." Among these are "samba de roda" (ring samba), the "ofício das baianas de acarajé" (craft of the acarajé-selling Bahian women), the "roda de capoeira" (capoeira circle) and the "ofício de mestre de capoeira" (craft of the capoeira master). In the dossier's introduction, Capone and Morais (2015b) point out that by 2015 , there were 30 records of intangible heritage filed by IPHAN, of which ro had to do with "Afro-Brazilian culture." In the same publication, Morais (20I5) states that since I984, eight Afro-Brazilian terreiros (worship places), had already been registered - the protective measure taken by IPHAN for material culture $^{4}$. The combination of state initiatives for heritage making that extends to terreiros and others that benefit various expressions of "Afro-Brazilian culture" - not coincidentally they are also found in events at Valongo Wharf - is what is intended to be learned with the term Afro-heritage. 
I start from this idea of Afro-heritage for reflecting upon a few of its underpinning conditions and interconnections. Before specifying this objective, it is necessary to state that the existence of Afro-heritage is the result of several forces (Capone \& Morais, 20I5a). Firstly, the struggle and engagement that the defenders of blackness and racial equality have been promoting on behalf of the fight against racism. Marker of the Ioo-year anniversary of the abolition of slavery as well as the year of the promulgation of the most recent Brazilian federal constitution, I 988 can act as a reference point for this struggle and engagement, even though these have an even longer history. Another factor to consider is the role of the government agencies that were involved with these issues and that, based on legal provisions and intervention plans, interact with practices associated with Afro-Brazilian meanings and collectives. There are also global issues, either in the ways of configuring identities related to Africa, or in the mechanisms for acknowledgment (as seen in the World Heritage instrument). Given this complex picture, my claim is simply to question a dimension that crosses through and helps to compose these various forces. Therefore, I distance myself from a more specific discussion about heritage and its policies to focus on the conditions that make the connection possible between religion and culture, found in heritage policies, but also in other government initiatives.

I think that the notion of culture, far from only describing what is covered by the idea of Afro-heritage, consists of that which interconnects it. In order to show this, and considering the views that address both Afro-Brazilian religions and state policies, I seek to understand how the ties between notions of religion and culture are strengthened. In a previous discussion (Giumbelli, 2008) about the formation of the so-called "Brazilian religious field," I already noted the unique association that is built between the universe of Afro-Brazilian religions and the idea of culture. More specifically: these religions are seen and treated as an expression or part of the African legacy in Brazil. It is through this ethnic aspect, grounded on anthropological concepts, that the idea of culture is elaborated for presenting and representing Afro-Brazilian religions. My aim here is to return to and specify this interpretation. In this context, I turn to the work of colleagues, whose research deserves appreciation. This text is also a tribute to these colleagues and an investment in the intellectual dialogues that their work encourage.

I will proceed by organizing the argument into three sections. First, I will focus on government measures that directly affect Afro-religious worship. I argue that an idea of "traditionality" is used as the foundation as much for cultural policies as for policies derived from other spheres. This is only possible when the definition of the terreiros is based on an ethnic notion of culture. Then I discuss several dimensions of the so-called combat against religious intolerance, having noted the prominence of Afro-Brazilian religions in that context. This prominence corresponds to a concept that interconnects two reactions: 
religious intolerance and racial inequality. Beyond racializing the debates, this shows one of the arguments afforded by defining Afro-Brazilian religions as culture. Finally, and still emphasizing traditionality, I draw attention to the ways that connections with the Afro-religious universe are created in the discourse that promotes the heritagization of acaraje and capoeira. These connections confirm how central the associations are between the notions of religion and culture. As a result, what I do is create a sort of cross-section of the Afroheritage universe and place the issue of religion at the center of the debate since it lays bare what I think is an indication of this universe: a certain notion of culture. Although the universes studied here are different, the idea is to demonstrate precisely how the association between Afro-Brazilian religions and culture is reiterated in them. This introduces possible connections with notions of Africanness and blackness that act either to support concepts of traditionality, which are key in the first and third sections, or to structure the rapport between the fight against religious intolerance and the fight against racism (second section).

This text, therefore, is a critical reflection on certain uses of the notion of culture. As suggested by Carneiro da Cunha (2009), it is about "culture in quotes" and situations that Wright (I999) would identify as the "politicization of culture." In the conclusions I recall a case in the United States, where the association between African-American religion and culture is not implemented. When this occurs, as it has in Brazil, it opens issues that act upon the meanings and forms that Afro-Brazilian religions engender in society, as is shown in the case of the Valongo Wharf, which I return to for the sake of illustrating my arguments. By noting the interconnection of religion and culture in different realms, it is not a matter of simply recording the occurrence of an idea, but rather, of accompanying the ways it is enacted in the composition between state policies and specific social practices. This corresponds to its circulation in certain spheres, which involve certain uses and effects based on meanings that I intend to point out.

\section{TERREIROS: THE CONTEMPORANEITY OF TRADITION}

In this section, I discuss the important research studies by Mariana Morais in relation to some of her findings (20I4, 20I5). She shows how IPHAN's I984 approval of the heritage site listing of a candomblé terreiro (worship place), in Salvador depended on changes in the very concept of heritage adopted by this federal agency created in I937. In her discussion of Gonçalves (I996), ${ }^{5}$ Morais (2014: I45-6) states that after the I970s, some changes in the notion of heritage enable an anthropologically-conceived approach "whose authority is based on a systematic theory of culture or society," and with an understanding of the "notion of Brazilian culture that emphasizes the present more than the past." This would clear the way for conditions that would broaden the meanings of 
heritage to cover non-material dimensions, which would in fact be established by rules starting in the early twenty-first century regarding "intangible heritage". IPHAN's heritage listing of another seven Afro-Brazilian terreiros by 2015 would be an expression of these changes, ${ }^{6}$ in contrast to the long period in which this never occurred, when only Catholic churches benefitted from being registered as heritage sites (Giumbelli, 20I4).

Despite pointing out the changes that enabled terreiros to be recognized as national heritage sites, Morais notes this policy's limitations. Eight or nine terreiros make up a rather small group given the size of the universe of Afroreligious institutions, whose number of temples comes close to the thousands in some Brazilian cities. Moreover, also according to the author, when these eight terreiros are identified, the observation is that this universe is limited in another sense: they are places, most of them in Salvador, which belong to a highly valued lineage based on criteria that celebrate faithfulness to African legacy. Morais (20I4: I59) concludes by saying that "although elements of AfroBrazilian culture are included in representations of the nation, the constitutive plurality of Afro-Brazilian religions is excluded." In other words, in the real world a certain type of religious practice and reference ends up being favored and anthropological acceptance of culture is tempered by another, less horizontal one, which is the basis on which we can state that certain examples are worthier of recognition than others.

I agree that this hierarchy exists.' It seems more appropriate, however, to attribute it to the mechanism itself instead of the criteria by which it is carried out. A governmental apparatus such as IPHAN is committed to the concept of creating a hierarchy of culture. Its mechanisms are set up to emphasize and distinguish and thus produce profiles and reliefs in the flat terrain that can be glimpsed when the idea of culture is "democratized." That "everyone has culture" may be accepted and celebrated; however, when dealing with "protecting" or "safeguarding," these measures are discriminating. This does not cancel the impact that adopting a more anthropological understanding of culture has had on IPHAN's work. When carefully studying the same procedures for heritage listing analyzed by Morais (Giumbelli, 20I4), I noted how, in the technical reports issued in favor of protecting the terreiros, architecture was no longer considered on its own and was now dependent on its collective and ritual uses. It is precisely an anthropological concept of culture that provides this view of architecture, which is characterized by a sort of "ethnicization" of the criteria that make it possible to appreciate the spatial configurations of terreiros. ${ }^{8}$

Should we wish to have a more comprehensive idea of how Afro-religious terreiros have been viewed by government measures, we must take a different tack. This is consistent with discussions that take place in the realm of IPHAN itself, when it recognizes the appropriateness and the limitations of landmark status as an instrument. In several states, laws and decrees have distinguished 
Candomblé and Umbanda as "intangible heritage." In the case of IPHAN, interestingly enough, this instrument has to this day favored Catholic feasts, even though it is common to see black or African facets in them. ${ }^{9}$ In any case, I reiterate, we must move beyond cultural policies to find the impact that government measures have had on the Afro-religious universe since that is where we will find other repercussions regarding the anthropological and "ethnicizing" understanding of culture applied to these religions. In other words, the scope of these measures has been much broader than that for measures that depend strictly on cultural policies. ${ }^{\text {Io }}$

Again, Morais (20I4) and Cordovil's (20I4) work provide fundamental elements to show this. These are associated with recent government policies aimed at promoting "racial equality." Morais draws attention to the cross-cutting nature of these policies, which are driven by laws such as the Statute for Racial Equality (20I0) and by documents that outline a "national policy" for this topic. The creation in 2003 of a federal agency, the Special Secretariat for Policies Promoting Racial Equality (Secretaria de Políticas de Promoção da Igualdade Racial, or SEPPIR), enhanced the holding of events and the creation of documents that brought about policies based on several rubrics. There have been initiatives in the field of health and education, for example, that involved terreiros. Another field is food security, in which we note initiatives that have operated more explicitly on two fronts: on the one hand, producing knowledge, which is fulfilled in "mapping" terreiros in different Brazilian cities and publishing them on websites and in books, on the other hand, promoting food distribution programs for families registered by terreiros. As noted by Cordovil (20I4), this government policy depends on an interconnection that conceives Afroreligious places of worship like knots in a net characterized by social vulnerability, but also as modes of being that are structured around an idea of "traditionality," - I believe this idea can also be found in reasons behind listing terreiros as heritage (Giumbelli, 20I4).

Here we touch upon a fundamental point of policies that "promote racial equality," alongside its cross-cutting aspect: the categories created and adopted for implementing them. Correctly noted by Morais (2014: I83), "promoting racial equality was [...] not only a way of fighting against racism, but also a way of guaranteeing respect for cultural diversity." The use of the terms "people" and/or "communities" accompanied by the adjective "traditional" is a result of this focus on cultural diversity. It can be said that the prototypes for this idea of "traditional" collectives are the ways that definitions are applied to indigenous peoples and maroon communities ("quilombos"). These forms are specified in a 2007 decree and bring together three basic elements: cultural differentiation, social organization of their own, and use of land for subsistence needs. Thus, these definitions cut out ways of life in their various dimensions and a certain relationship with land. Besides indigenous people and quilombolas, sev- 
eral other populations were included in this designation, such as "caiçara," "ribeirinho," and "sertanejo"; along with these, the "terreiro peoples."

In the case of Afro-Brazilian religions, this conceptual operation is tied to two effects. Firstly, there is the idea that the terreiro is a place that interconnects economic and social elements, which are guarantees for the transfer of "traditional knowledge" and channels for proposing community actions. The traditionality that emerges as an identifier of this configuration makes it possible for terreiros and other non-religious collectives to come closer together, as shown above. Secondly, there is the reiteration that in the case of religions Africanness be the source for producing cultural differentiation. In other words, a component of the way of life that is tied to the terreiros necessarily points at references held to be African - they are, according to a 2013 document (apud Cordovil, 20I4: 28I), "the continuation of African civilization in Brazil." This corresponds to changes in terminology starting in 20I 2, when official policies were adjusted from "traditional peoples and terreiro communities" to "traditional people and communities of African origin." Thus, the reference to Africanness was reinforced and suggested a new design for collectives by bringing religions closer to the quilombo communities.

It is notable that the transition from the field of heritage policy to the field of racial equality, which describes the path traced by this section of the text, reiterates the importance of the connection between religion and culture in recognizing Afro-Brazilian religions. The coupling of these two is so tight that one could say culture serves to define religious practices. Significantly, the 20I3 document just cited does not make any mention of the term "religion" (Morais, 20I4: 295). At the very least, government policies capable of addressing Afro-Brazilian terreiros and religious practices can be based on formulations that assume blackness as culture. This finding can therefore come as much from the field of cultural policies as from the field of the fight against racism. The basis in either is the same: in the case of Afro-Brazilian religions, religion is culture, and culture extends Africa to Brazil. Despite this, what is left over in recognizing something as being unquestionably religious supports another field of struggles and policies: "religious intolerance." Here again the link to the racial topic will be crucial.

\section{FIGHT AGAINST RELIGIOUS INTOLERANCE: FIGHT AGAINST RACISM}

Capone and Morais (20I5b) observe that I 988 is a crucial year for defining what they call Afro-heritage. It coincides with the new Federal Constitution in Brazil and is also the year that marks the roo-year anniversary of the abolition of slavery. In this context the authors place the drive that wins over the agenda of fighting racism and the legal recognition of procedures that would guarantee restoring the territories of "the remnants of quilombos." The same Constitution, the authors note, also enshrines the principle religious freedom by confirming 
and loosening previous norms. Religious freedom connects to the struggle for Afro-Brazilian religions through more recognition and due conditions for its practice. However, what could have been an integrated set of references focused on that fight ended up taking on other features. More specifically, although appealing to "religious freedom" has never been abandoned, the rallying call of preference for protecting Afro-Brazilian religions has been the combat "against religious intolerance." It can be shown - that is the point of this section - that by making Afro-Brazilian religions its dominant point of reference, "religious intolerance," takes on shapes that border those of confronting racism. In other words, we again encounter a way of defining these religions that is based on their relationship with blackness.

In this section I carefully monitor the discussion raised by Paula Montero (20I7), who heavily bases herself on the research of Milton Bortoleto (20I5), whose master's thesis addresses the topic. In this way, he comments on his own work:

As defended in previous work, the notion of "religious intolerance" emerges in Brazilian anthropological and sociological papers at the end of the I990s, when a group of priests from Afro-Brazilian religions and especially a set of academics start to use the term to refer to cases related to the category of research on the "religious conflict between Pentecostals and Afro-Brazilian religions," by replacing the term "holy war," which until then had been widely used by Pentecostal priests, the media and in academic literature (Bortoleto, 2015: 159).

Montero (20I7) lists several episodes that helped to consolidate this shift, which always involve disputes about the practices of the Universal Church of the Kingdom of God (Igreja Universal do Reino de Deus, IURD), nominated as the emblem of stubborn and belligerent neo-Pentecostalism: criminal cases motivated by a book that denounces mediumistic religions (I988), an attack on a Catholic image (I995), the use of a photo of a mãe de santo called a "macumbeira" (witch) and "charlatã" (quack) (I999). According to the author, the cause of "religious intolerance" would place disputes more squarely into the legal domain than "holy war."

Based on this finding, Montero (2017) draws attention to the use of Federal Law 7716/89 in these disputes. ${ }^{11}$ This is a law that refers to attempts to frame racism in legal terms at times to prejudice, at others to discrimination. In force since I989, it is in direct dialogue with another law that dates back to I95I and another one to I985. Montero (2017: 224) points out a change made in I997: "The articles in this law were designed to combat racial prejudice. Thus, its first draft in 1989 did not mention crimes related to religious discrimination. Its first draft said: crimes resulting from prejudice against race and color would be punished under the Law. Only eight years later, in May I997, was the law changed to include discrimination alongside prejudice and expand the range from race or color to ethnicity, religion and national origin, in this order". In 
the author's opinion, this would be evidence of making "racial discrimination" and "religious discrimination" equivalent. Although "religious intolerance" did not acquired legal status in the form of a specific crime, its connection to the entry into force of law 7716 and its amendment in I 997 make it central to ways of engaging in the name and in favor of Afro-Brazilian religions.

The discussion put forth by Montero includes a set of formulations (e.g.: Montero, 20I5, 20I6) that aim at understanding the constitution of secular spheres in Brazil through their relationships with religious arguments and agents or religious issues. The text mentioned here is mainly concerned with demonstrating that Brazil did not develop an appreciation of tolerance "as a civic virtue or a right to be conquered" (Montero, 20I7: 225). Tolerance is thus understood as a principle that should underpin procedures for regulating differences according to a necessary condition of equality and coexistence. By noting that religious intolerance has become an important guiding principle in public disputes, the author draws a conclusion: "[In Brazil] the concept of intolerance does not signify the inverse of tolerance but its inexistence. By emerging as a vice, tolerance loses its qualities as a political instrument for mediation of differences and its absence becomes a crime to be combated" (226). The discussion is interesting, but my goal in this text is different. The critical question has to do with the effects of putting the religious and racial fields on an equal footing. Seen from this perspective, advocacy against religious intolerance is revealing since it gives Afro-Brazilian religions prominence in a broader cause and because it draws a configuration that differs from that suggested by the principle of religious freedom.

The case studied by Bortoleto (2015) takes on a special value when considering these objectives. In 2008, the images of an Umbanda center in Rio de Janeiro were vandalized by the members of a Pentecostal church. The episode led to a lawsuit in which the framework of law 7716 was not considered until later on in the proceedings and as a result of interventions of the Commission for Combating Religious Intolerance of the State of Rio de Janeiro ${ }^{\text {I2 }}$. The leadership of this commission includes a "pai de santo" (priest) and an Umbanda medium. As a result of the Comission's activities, in 2010 the Police Department created a group for combating religious intolerance. The group's purpose was to systematize the "cases of religious intolerance" reported to police stations and to guide police to resorting to law 77 I6. In the case in question, the efforts resulted in what was reported to be "the first prisoners of [crimes against] religious intolerance in Brazil." Bortoleto highlights the linguistic shift between discrimination - a legal term - and intolerance - a word used in the descriptions of complaints. It is also important, however, to note the reactions by or on behalf of Pentecostals, who in turn resorted to the principle of religious freedom. The congregation they belonged to was renamed to incorporate the word "martyrs" and they declared the "Day of the Persecuted Pastor." 
This paints a portrait in which Afro-Brazilian leaders take on a fight that urges other religions to participate in the name of confronting "religious intolerance" and in which Pentecostals and their supporters defend "religious freedom." This picture reveals a redistribution of ideals and political principles if we start from the observation that religious freedom and the fight against religious intolerance can take strides together. Bortoleto (2OI5) systematizes the occurrence of a series of "marches" that for the past I 5 years have taken place in various Brazilian cities and combine these terms. The most popular of these marches assembled 200,000 people in Rio de Janeiro in 20 I I. However, if religious freedom and combating religious intolerance are combined in the marches, it is especially the latter that gains traction, embodied by appealing to specific legal provisions - namely, law 7716 was created with the purpose of confronting racism. It even has the support of a Federal decree from 2007, which made January 2I the National Day of Combating Religious Intolerance. The date is a reference to the death of the mãe de santo portrayed in a newspaper of the IURD, an episode mentioned by Montero (20I7).

Combating religious intolerance is the main focus of four videos published in 2015 and 2016 on Portal Brasil, an official website of the federal government. Three of the videos have images and personalities related to AfroBrazilian religions. At the same time, the federal government also launched a new campaign called "Filhos do Brasil" (Children of Brazil), with the following introduction: "an initiative with the objective of combating, from the perspective of Afro-Brazilian religions, an evil that has gradually reappeared and has reared its true face: religious intolerance." ${ }^{\text {13 }}$ Although the fight against religious intolerance is closely associated with Afro-Brazilian religions, there are indications that defending religious freedom has become a cause for evangelicals - at least by those who talk on its behalf in legislative spaces. As demonstrated in another paper (Giumbelli \& Scola, 20I6), issues tied to the rights and prerogatives of religious associations have mostly received the attention of religiously identified congressional representatives, who are almost always evangelical, in the National Congress. In this context, in which defending religious freedom and combating religious intolerance tend to have different configurations of agents and devices, what occurred in 20 Io is significant. At the time, a National Plan for Protecting Religious Freedom and for the Promotion of Public Policies for Traditional Terreiro Communities was announced. However, it never materialized, unlike the National Program for Sustainable Development of Traditional Peoples and Communities of African Descent, launched in 2013 (Morais, 20I4: 293). Given the different paths followed by competing claims, perhaps the combination of religious freedom and Afro-religious terreiros seemed, especially from the evangelical perspective, like a short circuit to be avoided. ${ }^{\mathrm{I}}$ 


\section{ACARAJÉ AND CAPOEIRA: CULTURE AND ITS APPEARANCES}

It is significant that the "Filhos do Brasil" campaign is promoted by Fundação Cultural Palmares and by the Ministry of Culture. Using this as a segue, in this section I return to the field of cultural policies, more specifically, to that of heritage in the context of IPHAN. I refer to the registry of aspects connected to a pair of "cultural assets" listed under the category of "intangible heritage": acarajé and capoeira. In 2005 the "ofício das baianas de acarajé" was approved as heritage. In 2008 , the same occurred with the "ofício dos mestres de capoeira" and "roda de capoeira." Making this "knowledge" and these "forms of expression" (categories adopted by IPHAN) involves a series of aspects, which range from those based on government policy in its dealings and rationales, to those that depend on the ways that practices like capoeira and food like acarajé are produced and reproduced. I propose discussing several points that raise the question of the relationship between these "cultural goods" and religion. We will see that this relationship is diverse, but at the same time it confirms the idea of privileged association between culture and Afro-Brazilian religions. As in the previous sections, I base myself on results from research on each of these realms; yet here I also consider materials available on IPHAN's website, including the reports and decisions produced in the context of making certain aspects of acarajé and capoeira heritage.

In IPHAN's heritage listing process, ${ }^{15}$ the technical report and the board's report agree with pointing out the origin and the relationship of capoeira with African references. According to the second document, "Capoeira is established on a reference to African cultural legacy, especially Bantu, in Brazil's diverse melting pot" and can be considered "an identity strategy for ethnic groups." Moreover, the technical report, which agrees with the Bantu origin of the practice, points out "the maintenance of values, ways of being in the world founded on Afro-Brazilian sociability prevalent in street life - values embodied by the capoeira practician." The capoeira circle with its moves and songs confirms, according to the technical report, this suitability, reiterated in a set of associations: "It is well known that without the circle, there is no candomblé, samba, jongo, tambor de crioula, ciranda, nor $\operatorname{coc}^{{ }^{16}}$. Nor capoeira."

These African references grant capoeira characteristics that are threatened by certain processes that make up part of its history. The board's report acknowledges that, "as a historically active cultural practice, capoeira is modified over the course of its historicity and thus creates its regional and 'contemporary' forms." The excerpt shows that the parameter used for considering the origins of capoeira is its so-called "Angola" variety, which is different from the "regional" and "contemporary" categories. The observation of this diversity is less important in the technical report than the concern over certain dangers: "despite its apparent health, the practice of capoeira runs the risk of - it continues to exist in its most outward form as a repertoire of movements and songs - losing its essence and its foundation, either because it will start to be 
taught by those who did not learn it in the framework of the tradition, but rather as a sport, and therefore do not know its proper cultural aspects, or because of the break in the transfer chain resulting from the departure or death of old masters who did not train new ones". I draw attention to the formulation that places "sport" in opposition to "culture" and to the association of the "proper cultural aspects" with the work of masters as disseminators of a traditional knowledge.

Besides the training in a circle, the way capoeira is disseminated is an aspect that would bring it closer to candomblé. The technical report tries to invest on that close tie when it states that capoeira has a "rich symbology based on Afro-Brazilian religion." This aspect, however, is not actually developed. There seems to be a certain difficulty in pinpointing this relationship between capoeira and "Afro-Brazilian religion." Even in a text purportedly dedicated to doing so (Abib, 20II), the connection advertised with "the mystery of AfroBrazilian religions" deals with the term "mandinga," in particular. Mandinga refers to both capoeristas' use of mojos (amulets) and the ever-praised fighting skills connected to powers of dissimulation. Significantly, the term is not mentioned in the IPHAN documents. Instead, these documents consider capoeira to be a "philosophy of life" and "a worldview" "that - according to the the board's report - are expressed in different configurations, such as playful, aesthetic, physical, or sport," which leads the technical report to consider it a "fight, dance, game, and play" all at once. As long as it allows this definition as a multifaceted and potentially self-sufficient universe, capoeira does not need to have a precise connection with Afro-Brazilian religions. Therefore, a similar relationship could be traced with aspects of Catholicism - for example, the reference songs make to saints and the capoeira circles performed in church atria.

Another relationship with the religious universe that is not mentioned in the IPHAN documents, but easily noticed by those interested in capoeira: evangelical religions. This point serves as a segue from capoeira to the case of acarajé. This is because in both of these we can note similar responses carried out on behalf of evangelical religions. On the one hand, there is the condemnation that associates capoeira or acaraje with something evil or demonic, and on the other, an appropriation that can be accompanied by a change in terminology, as shown by the expressions "capoeira de Jesus" (Jesus capoeira) and "bolinho de Jesus" (Jesus fritters). In the case of capoeira, however, this relationship with the evangelical seems to be less problematic. There is news of evangelical capoeira masters, some of whom are important; conversely, from an evangelical point of view, it is possible to practice capoeira without having to "come to Jesus." This confirms the idea that capoeira is itself a universe while being open to many other motivations. Now, in addressing acarajé, considering it to be merely a delicacy would be more plausible; nevertheless, the disputes over its meaning and its context are more dramatic. This is what we can ob- 
serve in the documents in the file that registers the "ofício das baianas de acarajé" as heritage. ${ }^{\text {I7 }}$

Just as occurs in the capoeira dossier, the technical report and the board's report about acarajé show historical démarches that aim to understand the changes undergone by these practices by using parameters considered to be "traditional." This approach makes it possible to make claims, such as this one by Évora (20I5: 47): "Acarajé went beyond the limits of religion and became an element of Salvador's culture as it was incorporated by various segments of its society." What is really at play, however, is the way this "culture" is recognized. The IPHAN documents show that clearly there is a narrative that seeks to connect acarajé to religious elements of candomblé. The technical report holds that "the making of acarajé was brought [to Brazil] by black slaves during the colonial period" and was rooted in the orixá religions. It is a "sacred food offered to deities in candomblé rituals." Even its "profane use" was initially related to religion, since it was "dues for initiating filhas de santo (female believers)." The board's report deepens this narrative by going into a certain amount of detail about the myth about Xangô and Oiá in relation to the "bolo de fogo" (fire cake) and when considering acarajé to be a food that "is part of a cultural complex that begins with its origin." The relationship with Afro-Brazilian religion is further reinforced by the request that initiated the heritage registration process, one of the authors of the request being a candomble terreiro, which was, by the way, listed by IPHAN.

Another author of the request was the Associação das Baianas de Acarajé, Mingau, Receptivos e Similares (Association of Bahian Women Who Make Acarajé, Porridge, Welcomes, etc., ABAM), which presents itself as an advocate of the traditions surrounding the tabuleiros (food stands) where acarajé is served in the streets of Salvador. The city's government directly intervened in the late I990s, proclaiming rules (ratified in 20I5) that, in addition to stipulating hygiene measures, made the garments that had to be worn when selling the delicacy official (Reinhardt, 2007 \& in press). It is based on the well-known image of the "baianas de acarajé" presented as part of the "Afro-Brazilian culinary tradition," with her skirts and baskets, but also "contas" (beads) and "búzios" (conch shells). This requirement is supported by ABAM. It is common for the evangelical women sellers of acarajé - or "bolinho de Jesus" - to question the need to wear such garments (even when they agree to use them). The technical report in the IPHAN file makes direct reference to acarajé's process of change, including its appropriation by evangelicals. Although it considers these changes to be unstoppable, it does not stop short of criticizing them: "In this regards to [acarajé de Jesus], there is also the recent emergence of acarajé in formal businesses, bars and supermarkets. The addition of the trade carried out by the baianas de acaraje to other cultural realms has generated market disputes, which contribute to weakening the traditional practice." And concludes: "They still pose the risk of a 
certain cleansing of undesirable cultural traits by the dominant sectors of society, as well as the consumerist normalization of food made by baianas."

The evangelical reactions to the government regulations on the sale of acarajé are interesting because they lead to explicating the arguments underpinning the traditionality associated with the delicacy. This is not the place to describe or analyze them. Suffice it to say that they open the possibility of seeing how the topic of acarajé's traditionality is surrounded by three distinct and interconnected layers. The food layer, with its methods of production and sale; the garment layer, standardized within a certain understanding; and the religious layer, which to many is inherent in the food, but that also sets up the differences between the terreiro and the street. On the one hand, the acarajé sellers who are connected to candomblé - a smaller proportion of the universe, by the way - might follow a few precepts in keeping their acarajé stands. On the other hand, the rules surrounding the production, use, and consumption of the food at the terreiro are not the same as those applied to the delicacies served on the street (Bitar, 20I I; Reinhardt, in press). The possibility for conjunctions and disjunctions between these dimensions are put into action with arguments that defend the use of standardized garments, at times defining acarajé as a derivative of "religion," and at others resorting to "culture" as a way to legitimize certain vestments.

The transition from "religion" to "culture" is precisely shown in attempts to respond to certain evangelical complaints. Here I make use of information and reflections provided by the work of Reinhardt (2007 \& in press). This researcher tells us that regarding the regulation for the attire worn by the acarajé saleswomen in Salvador, evangelical council members reacted by assigning a violation to the secular principle of government. Given this argument, defenders of mandatory traditional dress displace its basis to the idea of "culture," as in this case recorded by Reinhardt (2007: 106): "Whether Spiritist, evangelical, candomblé, or not, it is a market that can be explored by anyone [...]," but "they actually have to dress up as a baiana, it is the permanence of a tradition in the city's culture, and not of a religion." Similarly, the president of ABAM took a position in the records of Évora (2015: 44): "the acarajé saleswoman has to be at her stand in her robe, skirt and 'torço' (headscarf) regardless of her religion."

To conclude the analysis I put forth about these two cases, above all considered in their involvement with heritage-making measures that are in IPHAN's purview, I emphasize a few points. The first has to do with the ways in which acarajé and capoeira are connected to certain views of culture. In both cases, considering such "cultural" practices depends on narratives that seek to understand the present based on the past. In both, the characterization as "cultural" is also connected to the emphasis placed on its origins and/or connections with Africanness. This Africanness includes religious elements, but also the way that the interconnections are presented is significantly different. 
In capoeira, religion is simultaneously diffuse and invisible. The evangelical appropriation does not seem to raise much concern. Perhaps because it's not considered as being strong enough to break down the ways of practicing and reproducing capoeira ${ }^{18}$. In the case of acarajé, however, evangelical appropriation generates strong reactions. What is interesting is that the criticism of this appropriation can be made in the name of "culture," as seen above. More importantly: viewed either as "culture," or "religion," the forms that accompany the sale of the food will be the same - the "baiana de acaraje" and the parameters that refer to marks of Africanness. The approximation of Afro-Brazilian religion and culture, as shown in this reasoning, undergoes a new confirmation.

\section{ENDNOTES: COUNTERPOINT AND REFRACTIONS}

I begin these final notes by bringing up a case that did not occur in Brazil, and therefore has the advantage of making the constructions that exist in our country clearer. In fact, this is not a matter of "national differences," but of the characterization of arguments that underpin certain ideas, instead. In any case, what I introduce below is useful for better understanding the construction of these arguments ${ }^{19}$. I make use of the description and the analysis Stephan Palmié (I996) made of this case. It involves the performance of animal sacrifice by a santería church - one of the forms adopted in the Caribbean by the cult of the orixás - which moved its facilities to a central location in Hialeah, Florida, near Miami. Although a significant portion of the population is Cuban-American, reactions to this practice led the city council to approve a law prohibiting the death of animals in religious ceremonies. The santero leaders reacted and got the Supreme Court of the United States to unanimously quash the law. Palmié (I996: I94) suggests that the verdict "is of considerable legal interest, for it may play a future role with respect to issues associated to the debate over 'multiculturalism." That said, he understands "the concern over the preservation of a 'way of life' structured by religious precepts."

The author may be right about the consequences of a decision like this one, but the basis for the decision in favor of santeros does not appeal to this "multiculturalist" argument. In fact, at no point is the word "culture" mentioned in the decision nor in its accompanying votes. ${ }^{20}$ The judges seek other reasons for considering that the city law infringed upon the principle of religious freedom enshrined in the First Amendment to the United States Constitution. They are presented by Palmié (I996: I84-I85), himself in his text. Firstly, historical records of animal sacrifice for religious purposes (in Judaism, for example) consider the claim by the santeros that the same practice also be an integral part of their religion. Secondly, for the judge who issued the decision, "although the practice of animal sacrifice may seem abhorrent to some, religious beliefs need not be acceptable, logical, or comprehensible to others in order to merit First Amendment protection". When these arguments are compared, they may seem 
contradictory, one reinforcing the credibility of the practice, the other negating its necessity. However, both are founded in a modern view of religion, which is as useful for historicizing it as for defining it in terms of beliefs that do not require any basis other than the adherence of its followers (Giumbelli, 20I I).

This reasoning characterizing santería as a religion in a more or less strict sense is confirmed in the decisive argument of the sentence. The reasoning is guided by the idea that there should be a treatment that holds santeros to the same requirements as other citizens. The judges decide that this did not take place, since the municipal rule was carefully drawn up for prohibiting only slaughters carried out in santería institutions. For example, it cannot incriminate hunters, who are not supervised, either, in the way they turn their prey into food. This reasoning also shapes the discussion about health problems arising from the disposal of animal remains, which can be created by "non-religious conduct." Palmié (I996: I94) explains the Supreme Court's requirements in these terms: "The law must incriminate the same type of behavior on a secular, socially inclusive level." It is important to note that the decision does not cancel the government's power to regulate religious practices; it simply conditions this power to equal treatment. Anyway, at no moment does the sentence in this particular case consider the specific origin of santería; nor does it introduce its precepts as part of a "way of life" or "tradition." In short, "religion" is not recognized or protected as "culture."

It is important to note that, on the other hand, the connection between religion and culture, when it occurs, can undergo challenges and fluctuations. The case I started this text with is proof of this. The cleansing of the Valongo Wharf is part, in fact, of a dispute over the meanings and occupations of the space where it occurs since, as pointed out by Carneiro and Pinheiro (20I5), the City of Rio de Janeiro preferred to invest in the idea of a "circuit of African heritage." This idea is devoid of or merely suggests references to religion. Moreover, the circuit adds the ruins of the wharf to other points that are part of the recent reforms, including cultural centers. The underlying narrative makes it possible to combine the reprehensible past of slavery with the present, which celebrates development. The "culture" that is cultivated in this idea dissolves religion into the body of remnants and ruins that fulfill the function of teaching about the past in order to make the present somewhat more enlightened.

Carneiro and Pinheiro (2015) bring together elements that show how another enlightened future was in mind for the Valongo Wharf. One of these elements was the idea of building a memorial with objects from "black culture," thus bringing together pieces that are the result of archaeological work in the neighborhood. This memorial would not be limited to a narrative of a more or less remote history of the African presence in the place associated with the Valongo Wharf. In fact, what is at stake is the production of what we could call the ancestry of the present. This idea would confer a privileged space to the current representatives of African legacies. ${ }^{21}$ In this context, religion would 
continue to be key since the construction of "black culture" would be one of the main sources of African memory in the present. At the same time, this rather "ethnicized" concept of religion makes it possible to form alliances that would have much broader horizons. Given the statements that Carneiro and Pinheiro (2015: 394) recorded of one of the black leaders who pronounced himself during the cleansing of Valongo Wharf in 20I4, the place would not be "sacred" just "for Afro-descendants, [...] but for all those who feel indignant about the history of slavery of black Africans."

The encounter of religion and culture thus produces different possibilities for meaning for each of these notions. A final example of this can be found in the work of Jorge Scola Gomes (2017), which takes us back to the topic of sacrificial practices discussed by Palmié. Scola Gomes records the positioning of a priest in the context of a recent battle against a legislative amendment that could risk animal sacrifice in practices related to the orixá cult. It is an explanation about the role of the State Council of the Terreiro People, an initiative of the government of Rio Grande do Sul, whose activities have been taking place over the last few years. We are therefore still grappling with the interconnections that are created between the state and religions. But what is at issue is precisely the meaning of an idea of "religion." The babalorixá (candomblé priest) states: "The Council is not for a religion, it is for overseeing public policies about a tradition, about traditional practices" (Scola Gomes, 20I7: I25). In this case, the notion of "tradition" - and we know its close relationship with the category "culture" - includes and expands the notion of "religion."

A historically wide-ranging perspective provides a glimpse of what seems to be a persistent non-framing of practices associated with the cult of orixás by the notion of religion in its (supposedly) unqualified forms. At the beginning of the republican era, when the Brazilian state declared its commitment to religious freedom (Giumbelli, 2008), there were obstacles to recognizing these practices as eligible for such freedom. The prevailing opinion would rather treat them as "sorcery," "magic," and "superstition" (Maggie, I992). At the beginning of the twenty-first century, the idea of "culture" seems to have been consolidated as the way that various expressions of worshiping the orixás are considered. This certainly does not prevent these expressions from also being categorized as religious. However, the notion of "religion," when applied to these practices, is simultaneously conferred meanings and possibilities that do not apply when dealing with other "religions." The challenge, therefore, is to try to understand the situations, concepts, and mechanisms by which associations, dissociations, and inflections are produced between "religion" and "culture." 
Emerson Giumbelli is Associate Professor of the Federal University of Rio Grande do Sul (UFRGS) and belongs to the Department of Anthropology and to the Graduate Program in Social Anthropology. Ph.D. in Social Anthropology from the Federal University Rio de Janeiro (UFRJ). He is co-editor of the journal Religião e Sociedade, and author of various books, including Símbolos religiosos em controvérsias (2014), O fim da religião: dilemas da liberdade religiosa no Brasil e na França (2002), and O cuidado dos mortos: uma história da condenação e legitimação do espiritismo (1997). He also co-edited, among others, the books Secularisms in the postsecular age? Religiosities and subjectivities in comparative perspective (20I7), and Religión, cultura y política en las sociedades del siglo XXI (20I3). 


\section{NOTES}

I This article is part of the results from the project, "Religião, cultura e espaços públicos" (Religion, Culture, and Public Spaces), sponsored by a CNPq (National Scientific and Technological Development Council) productivity grant. Its findings draw on readings and discussions held in the context of the discipline "Society and Culture in Brazil (Uses of the notion of culture in its relationship with religion)," offered in 2016 at the PPGAS (Graduate Program in Social Anthropology) at UFRGS (Federal University of Rio Grande do Sul). I appreciate the comments from Mariana Morais and Bruno Reinhardt, as well as the recommendations contained in the journal's editorial evaluation.

2 Acarajé is a dish made from peeled beans formed into a ball and then deep-fried in dendê (palm oil).

3 Capoeira is an Afro-Brazilian body practice that combines elements of dance, acrobatics and music.

4 For definitions on the listing of material heritage, the registry and inventory of intangible heritage, go to the IPHAN website: http://portal.iphan.gov.br/pagina/detalhes/218. Accessed on Feb. 23, 2017. According to Morais (personal correspondence, June 2017), there are now nine terreiros on the IPHAN registry.

5 The work of Gonçalves (I996) was established as a point of reference in the thinking about policies for heritage in Brazil and its multiple impacts. Also see Gonçalves (2007) for the repercussions of previous thinking and evaluations of assumptions and the ramifications of this important field of social policy.

6 Also see Gomes (20I0), a first effort in thinking about the listing of terreiros as heritage.

7 See the discussion on this put forth by Sansi (2007), incorporated by Morais (2014, 20I5).

8 Morais (2014: I92ss) fears that the limitations outlined end up favoring an idea of candomblé as a "canned religion"; but, in the same study (Giumbelli, 20I4), I aim to show how heritage listing is sought to be compatible with the requirement that they are constantly changing spaces given the principles and activities of the terreiros. See, on 
this aspect, the discussion by Gilberto Velho (2006), an anthropologist who is directly involved with IPHAN's decisions in the Ig80s.

9 A few examples, in line with the above-mentioned IPHAN website: círio (candlelight procession) of Nossa Senhora de Nazaré de Belém (PA); feast of the Divino Espírito Santo de Pirenópolis (GO); feast of Sant'Ana de Caicó (RN); feast of the Divino Espírito Santo de Paraty (RJ); feast of Senhor Bom Jesus do Bonfim de Salvador (BA); festivities of the glorious São Sebastião in the Marajó region; oxcart festival of the feast of the Divino Pai Eterno de Trindade (GO).

Io Also in in the field of federal cultural policies, I draw attention to the importance of recognizing the Pontos de Cultura (Points of Culture). Available at <http:// www.cultura.gov.br/pontos-de-cultura I > and <http:// culturaviva.gov.br/>. Accessed on 23/2/2017. Activities whose headquarters are Afro-religious temples have been contemplated by this policy.

I I The text of Act 7716 can be found at <http://www.planalto.gov.br/ccivil_03/leis/L7716.htm >. Accessed on $8 / 3 / 2017$.

I 2 Regarding these initiatives by religious people in Rio de Janeiro and the participation of government agents, see Miranda (2012, 20I4).

I3 Cf. news on the Fundação Palmares website: <http:// www.palmares.gov.br/?p=39585>. Accessed on 23/2/2017.

I4 This argument ought to be tested based on the work of Vital da Cunha (2014), which traces the profiles in the National Congress of the Frente Parlamentar Evangélica (Evangelical Parliamentary Front) and the Frente Parlamentar em Defesa das Comunidades Tradicionais de Terreiro (Traditional Terreiro Community Parliamentary Defense Front). It is also worth noting that evangelicals do not tend to circulate in the same networks established by the notion of culture in the sense that allow positive relationships between the state and Afro-Brazilian religions. In contrast, evangelical exponents explore other meanings of culture to establish relations with the government. These meanings are related to the world of entertainment (Giumbelli, 2008; Sant'Ana, 2013). 
I5 The documents related to the heritage listing process for the capoeira circle and the vocation of the capoeira master are available at <http://portal.iphan.gov.br/pagina/ detalhes/228>. Accessed 23/6/2016. Also see Vassalo (2012).

I6 Samba, jongo, tambor de crioula, ciranda, and coco are all examples of traditional dance and music that can be found in Brazil.

I7 The documents related to the process of heritage listing of the craft of the baianas de acarajé are available at $<$ http://portal.iphan.gov.br/pagina/detalhes/228>. Accessed 24/6/20I6. Also see Bittar (20II). Reinhardt's critical reflections (in press) reinforce and expand the argument supported here.

I8 The most feared threat seems to come with endeavors that would change capoeira into a sport and tie its teaching to training in physical education. See, for example, $<$ http://www.brasil.gov.br/cultura/20I3/II/iphan-discutecom-capoeiristas-regulamentacao-da-profissao $>$. Accessed on $24 / 2 / 2017$.

I9 Other works that explore the changing relationships between religion and culture in cases related to blackness in Brazil: Johnson (2005), van de Port (2005) and Selka (20I5).

20 Precisely the opposite is true in the official Brazilian document studied by Morais (20I4) about the "traditional peoples and communities of African origin."

2I This privileged place is recognized by the university team of archaeologists when it requires the help of Afro-Brazilian priestesses for identifying objects found in the excavations (Carneiro \& Pinheiro, 20I5).

\section{BIBLIOGRAPHY}

Abib, Pedro. (20II). A capoeira e seus aspectos mítico-religiosos. Textos do Brasil, I4. Available at <http://dc.itamaraty.gov.br/imagens-e-textos/revista-textos-do-brasil/ portugues/revistai4-mat9.pdf. Accessed on 13/06/2016. Bitar, Nina Pinheiro. (20II). Sistemas culinários afro-brasileiros: as baianas de acarajé do Rio de Janeiro. Textos 
Escolhidos de Cultura e Arte Populares, Rio de Janeiro, 8/I, p. I93-206.

Bortoleto, Milton. (20I5). "Não cultuais imagens de escultura". Alguns aspectos do debate público acerca da tipificação jurídica da "intolerância religiosa" e da "liberdade religiosa”. In: Montero, Paula (org.). Religiões e controvérsias públicas: experiências, práticas sociais e discursos. São Paulo/ Campinas: Terceiro Nome/Ed. Unicamp/Fapesp, p. I27-I62. Capone, Stefania \& Morais, Mariana. R. (orgs.). (20I5a). Afropatrimoines. Les Carnets du Lahic, II.

Capone, Stefania \& Morais, Mariana R. (2015b). De la négation à l'affirmation: le processus d'institutionnalisation du patrimoine culturel afro-brésilien. Les Carnets du Lahic, I I, p. 6-24.

Carneiro da Cunha, Manuela. (2009). "Cultura" e cultura: conhecimentos tradicionais e direitos intelectuais. In: Cultura com aspas. São Paulo: Cosac Naify, p. 3II-373.

Carneiro, Sandra de Sá \& Pinheiro, Marcia L. (20I5). Cais do Valongo: patrimonialização de locais, objetos e herança africana. Religião \& Sociedade, 35, p. 384-40I.

Cordovil, Daniela. (2014). On the border between culture and religion. Public policies for Afro-Brazilian religions in Brazil. Vibrant - Virtual Brazilian Anthropology, II/2, p. 268-287.

Évora, Lígia. (20I5). Do acarajé ao bolinho de Jesus. In: Giumbelli, E. \& Tavares, F. (orgs.). Religiões e temas de pesquisa contemporâneos: diálogos antropológicos. Salvador: Edufba, p. 33-52.

Giumbelli, Emerson. (20I4). Recomposing the nation: conceptions and effects of heritage preservation in religious universes. Vibrant - Virtual Brazilian Anthropology, II/2, p. 442-469.

Giumbelli, Emerson. (20II). A noção de crença e suas implicações para a modernidade: um diálogo imaginado entre Bruno Latour e Talal Asad. Horizontes Antropológicos, 35, p. 327-356.

Giumbelli, Emerson. (2008). A presença do religioso no espaço público: modalidades no Brasil. Religião \& Sociedade, 28/2, p. 80-IoI. 
Giumbelli, Emerson \& Scola, Jorge. (2016). A liberdade religiosa no Congresso Nacional. In: Vital da Cunha, Christina \& Araújo, Melvina (orgs.). Religião e Conflito. Curitiba, p. I9-39.

Gomes, Edlaine C. (2010). Dinâmica religiosa e trajetória das políticas de patrimonialização: reflexões sobre ações e reações das religiões afro-brasileiras. Interseções, I2, p. I3I-I58.

Gonçalves, José Reginaldo Santos. (2007). Antropologia dos objetos: coleções, museus e patrimônios. Rio de Janeiro: Instituto do Patrimônio Histórico e Artístico Nacional.

Gonçalves, José Reginaldo Santos. (I996). A retórica da perda: os discursos do patrimônio cultural no Brasil. Rio de Janeiro: Editora UFRJ/Iphan.

Johnson, Paul C. (2005). Three paths to legitimacy: African diaspora religions and the State. Culture and Religion, 6/I, p. 79-I05.

Maggie, Yvonne. (I992). Medo do feitiço: relações entre magia e poder no Brasil. Rio de Janeiro: Arquivo Nacional.

Miranda, Ana Paula M. (20I4). Como se discute religião e política? Controvérsias em torno da "luta contra a intolerância religiosa" no Rio de Janeiro. Comunicações do ISER, 69, p. 10-23.

Miranda, Ana Paula M. (20I2). A força de uma expressão: intolerância religiosa, conflitos e demandas por reconhecimento de direitos no Rio de Janeiro. Comunicações do ISER, 66, p. $60-73$.

Montero, Paula. (2017). The "culture of justification" in the production of public religiosities in Brazil. In: Mapril, José et al. (orgs.). Secularisms in a postsecular age? Religiosities and subjectivities in comparative perspective. New York: Palgrave, p. 207-229.

Montero, Paula. (20I6). "Religiões públicas" ou religiões na esfera pública? Para uma crítica ao conceito de campo religioso de Pierre Bourdieu. Religião \& Sociedade, 36/I, p. I 28 -I50.

Montero, Paula. (20I5). Introdução. In: Montero, Paula (org.). Religiões e controvérsias públicas. Experiências, práticas sociais e discursos. São Paulo: Terceiro Nome/Ed. Unicamp. 
Morais, Mariana R. (2015). Les religions afro-brésiliennes en tant que patrimoine: du conflit à l'institutionnalisation. Les Carnets du Lahic, II, p. 98-II8.

Morais, Mariana R. (20I4). De religião a cultura, de cultura a religião: travessias afrorreligiosas no espaço público. Tese de Doutorado. Pontifícia Universidade Católica de Minas Gerais.

Palmié, Stephan. (I996). Which center, whose margin? Notes towards an archaeology of U.S. Supreme Court Case 9I-948, I993. In: Harris, O. (org.). Inside and outside the law. London: Routledge, p. I84-209.

Reinhardt, Bruno. (in press). Intangible heritage, tangible controversies: the baiana and the acarajé as boundary-objects in contemporary Brazil. In: Meyer, Birgit \& Van der Port, Mattijs (orgs.). Sense and essence: aesthetics of persuasion in heritage politics. London: Berghahn.

Reinhardt, Bruno. (2007). Espelho ante espelho: a troca e a guerra entre o neopentecostalismo e os cultos afro-brasileiros em Salvador. São Paulo: Attar.

Sansi, Roger. (2007). Fetishes and monuments: Afro-Brazilian art and culture in Bahia. New York: Berghahn Books.

Sant'Ana, Raquel. (2013). A música gospel e os usos da "arma da cultura". Intratextos, Rio de Janeiro, 5/I, p. 23-4I. Selka, Stephen. (20I5). Our Lady of the Good Death: AfroCatholic festivals as cultural heritage in Brazil. Les Carnets du Lahic, II, p. I99-2I7.

Scola Gomes, Jorge. (2017). Outridade, conflito e governo: controvérsias públicas acerca da prática sacrifical afro-religiosa (Rio Grande do Sul, 20I5/20I6). Dissertação de Mestrado. PPGAS/Universidade Federal do Rio Grande do Sul.

Van de Port, Mattijs. (2005). Candomble in pink, green and black. Re-scripting the Afro-Brazilian heritage in the public sphere of Salvador, Bahia. Social Anthropology, I3/I, p. 3-26.

Vassallo, Simone. (2012). De quem é a capoeira? Considerações sobre o registro da capoeira como patrimônio cultural imaterial do Brasil. Cultures-Kairós, Capoeiras - objets sujets de la contemporanéité. Available at <http:// revues.mshparisnord.org/cultureskairos/index. php?id=580 >. Accessed on 4/5/2018. 
Velho, Gilberto. (2006). Patrimônio, negociação e conflito. Mana, I2/I, p. 237-248.

Vital da Cunha, Christina. (2014). Religiões X democracia? Reflexões a partir da análise de duas frentes religiosas no Congresso Nacional. Comunicações do ISER, 69, p. II9I30.

Wright, Susan. (I999). The politicization of 'culture'. Anthropology Today, I4/I, p.7-I5. 


\section{QUANDO RELIGIÃO É CULTURA: OBSERVAÇÕES SOBRE POLÍTICAS ESTATAIS DIRIGIDAS A RELIGIÕES AFRO-BRASILEIRAS E OUTROS AFROPATRIMONNIOS}

Resumo

Para demonstrar esse argumento, trabalhos de diversos pesquisadores são sistematizados, compondo uma discussão em três partes. A primeira enfoca medidas estatais que atingem diretamente terreiros afrorreligiosos. Em seguida, são discutidas algumas dimensões da luta contra a intolerância religiosa, constatado o protagonismo que as religiões afro-brasileiras nela ocupam. Por fim, mostram-se conexões com o universo afrorreligioso nos discursos que suportam a patrimonialização do acarajé e da capoeira. Assim, alguns elementos do universo dos afropatrimônios, sobretudo nos seus vetores religiosos, são analisados, para revelar aquilo que seria um articulador desse universo - a noção de cultura em um sentido étnico.

\section{WHEN RELIGION IS CULTURE: OBSERVATIONS ABOUT STATE POLICIES FOR AFRO-BRAZILIAN RELIGIONS AND OTHER AFRO-HERITAGE} this argument, which serves as the discussion presented here in three sections. The first focuses on government measures that directly affect Afro-Brazilian terreiros (ceremonial places). Next, some dimensions of the struggle against religious intolerance are discussed with a look at the leadership role Afro-Brazilian religions play in this regard. Finally, the article points out connections between the Afro-religious universe and the discourse in support of designating acarajé and capoeira as heritage. Thus, some elements of the universe of Afro-heritage, especially in the area of religion, are studied to highlight what is at the heart of this universe - the notion of culture in an ethnic sense.
Palavras-chave

Religiões afro-brasileiras; patrimonialização; cultura; intolerância religiosa; acarajé.

Keywords

Afro-Brazilian religions; heritage; culture; religious intolerance; acarajé. 